\title{
ADDUCTOR POLLICIS MUSCLE AS PREDICTOR OF MALNUTRITION IN SURGICAL PATIENTS
}

\author{
Músculo adutor do polegar como preditor de desnutrição em pacientes cirúrgicos \\ Camila Yandara Sousa Vieira de MELO, Silvia Alves da SILVA
}

From the Serviço de Nutrição do Hospital Universitário Oswaldo Cruz da Universidade de Pernambuco (Service of Nutrition, Oswaldo Cruz University Hospital, University of Pernambuco), Recife, PE, Brazil.

HEADINGS - Nutritional status. Adults. Surgery.
ABSTRACT - Background - In the compromised nutritional status, there is excessive skeletal muscle loss and decreased inflammatory response, contributing to increased morbidity and mortality and length of stay. Aim: To estimate the prevalence of malnutrition by measuring adductor pollicis muscle using cutoffs for surgical patients suggested in the literature. Methods: Cross-sectional study with 151 patients scheduled for elective surgical procedure. Nutritional assessment was performed by classical anthropometric measurements: arm circumference, triceps skinfold thickness, arm muscle circumference, corrected arm muscle area, BMI and percentage of weight loss and the extent of the adductor pollicis muscle in both hands. Results: The prevalence of malnutrition in patients was high. A significant association between nutritional diagnosis according to the measures of adductor pollicis muscle and arm circumference, BMI and triceps skinfold thickness but there was no association with arm muscular circumference, arm muscular area or percentage of weight loss. Conclusion: The adductor pollicis muscle has proved to be a good method to diagnose muscle depletion and malnutrition in surgical patients.

\section{Correspondence:}

Camila Yandara Sousa Vieira de Melo.

E-mail: yandara.nutri@yahoo.com.br

Financial source: none

Conflicts of interest: none

Received for publication: 10/09/2013 Accepted for publication: 17/12/2013

DESCRTORES - Estado nutricional. Adultos. Cirurgia.
RESUMO - Racional: No estado nutricional comprometido, há excessiva perda muscular esquelética e diminuição da resposta inflamatória, contribuindo para o aumento da morbimortalidade e do tempo de internamento. Objetivo: Estimar a prevalência de desnutrição pela medida do músculo adutor do polegar utilizando pontos de corte para pacientes cirúrgicos sugeridos na literatura. Métodos: Estudo de corte transversal com 151 pacientes candidatos a procedimento cirúrgico de caráter eletivo. Realizou-se avaliação nutricional através das medidas antropométricas clássicas: circunferência do braço, dobra cutânea tricipital, circunferência muscular do braço, área muscular do braço corrigida, IMC e percentual de perda ponderal e pela medida do músculo adutor do polegar em ambas as mãos. Resultados: A prevalência da desnutrição nos pacientes avaliados foi elevada. Houve associação significativa entre o diagnóstico nutricional, segundo o músculo adutor do polegar, e as medidas da circunferência do braço, prega cutânea tricipital e IMC. No entanto, não se associou à circunferência muscular do braço, área muscular do braço corrigida ou ao percentual de perda de peso. Conclusão: O músculo adutor do polegar mostrou ser bom método para diagnosticar a depleção muscular e a desnutrição nos pacientes cirúrgicos. which may be associated to the previous nutritional status with regard to the underlying disease or even to their treatment ${ }^{10}$. According to Celano ${ }^{7}$, malnutrition has an important role as a prognostic factor in infections and risk of complications in the postoperative period since, with compromised nutritional status, there 
is excessive skeletal muscle loss and decreased inflammatory response, contributing to increased mortality and hospital length of stay.

The metabolic response to surgical stress is often associated with increased concentration of catabolic hormones causing protein degradation and increased muscle proteolysis. These changes are proportional to the severity of the injury, and may itself compromise the clinical outcome 25. When coupled with a nutritional base deficit, the situation becomes even more severe ${ }^{24,26}$.

Lean mass has been evaluated by measuring the arm circumference, triceps skinfold thickness and then it was estimated the arm muscle circumference and corrected arm muscle area. However, these estimates are the result of calculations derived from muscle circumferences and skinfold thicknesses, which can hamper the interpretation of results. The adductor pollicis muscle (APM) is the only one in the human body that allows the direct measurement of its thickness ${ }^{18}$. This parameter has been used as a muscle compartment booking, for being a simple, rapid, non-invasive and low cost method $^{1}$. In the patient, the extent of the APM may reflect the loss of working capacity due to limitations in physical activity or work on behalf of the underlying disease, thus interfering with muscle trophicity and consequently the thickness of muscle? .

This study aims to estimate the prevalence of malnutrition by measuring the APM using cutoffs for surgical patients suggested in the literature.

\section{METHODS}

The project was approved by the Ethics Committee on Human Research of the Oswaldo Cruz University Hospital, University of Pernambuco under number 012/2011. The included patients were informed about the study objectives and signed a written informed consent in accordance with Resolution 196/96 of the National Health Council.

The study was conducted in the surgical clinic of the University Hospital Oswaldo Cruz, where the surgeries are elective. This was a cross-sectional study, which involved adults and elderly patients who were in proper physical condition to perform the assessment procedures within 72 hours after hospital admission.

The exclusion criteria were: patients referred from other clinics with a history of prior hospitalization exceeding $72 \mathrm{~h}$; patients who had edema of upper extremities; patients with AIDS or kidney disease on dialysis, and patients eligible for bariatric surgery.
Information contained in medical records as well as information collected from individual interviews with the patient or caregiver and annotated in a specific form for the research and the application of a questionnaire containing information such as gender, age, clinical diagnosis and anthropometric nutritional assessment were used. Were evaluated: weight, height, calculation of BMI, arm circumference, triceps skinfold, calculated arm muscle circumference and corrected arm muscle area thickness of the adductor muscle of the thumb of the dominant and non-dominant adductor pollicis hands and percentage of weight loss.

The body weight of those patients able to ambulate was measured using a scale type Filizola (B) platform with a capacity of $140 \mathrm{~kg}$, ranging from $100 \mathrm{~g}$. For bedridden patients, it was applied the equation of Chumlea et al. ${ }^{9}$ to estimate weight. Height was measured using metallic vertical stadiometer $2 \mathrm{~m}$ in patients able to ambulate while bedridden were estimated from knee height and applied in Chumlea et al. ${ }^{9}$. From the data of height and weight it was calculated the BMI. The diagnosis of nutritional status for adults was determined in accordance with the criteria established by the World Health Organization ${ }^{27}$, while for elderly it was used the diagnostic criteria proposed by Lipschitz ${ }^{19}$. The usual weight was reported by the patient and percentage of weight loss allowed the classification of nutritional status according to Blackburn and Bistrian ${ }^{3}$.

The database was created in Excel for Windows, version 2010. Statistical analysis was performed using the Statistical Package for Social Sciences (SPSS) version 13.0 (SPSS Inc., Chicago, IL, USA). Continuous variables were tested for normality with the aid of Kolmogorov-Smirnov test. All variables were normally distributed and were described as mean and standard deviations. The mean dominant and non-dominant hands were compared by t-student test for two independent variables. The chi-square test was used for comparison of frequencies being considered $p<0.05$ to reject the null hypothesis.

\section{RESULTS}

One hundred and fifty one patients were evaluated, with a mean age of $51.91 \pm 15.78$ years, of which the majority were female and adult. The most frequent diagnoses were cancers of the gastrointestinal tract, followed by biliary and liver diseases, however no significant difference in prevalence (Table 1). 
TABLE 1 - Characteristics of surgical patients by gender, life stage and diagnosis

\begin{tabular}{|c|c|c|c|}
\hline VARIABLES & $\mathrm{N}$ & $\%$ & IC95\% \\
\hline \multicolumn{4}{|l|}{ GENDER } \\
\hline Male & 61 & 40,4 & $32,6-48,7$ \\
\hline Female & 90 & 59,6 & $51,3-67,4$ \\
\hline \multicolumn{4}{|l|}{ STAGE OF LIFE } \\
\hline Adults & 96 & 63,6 & $55,3-71,1$ \\
\hline Seniors & 55 & 36,4 & $28,8-44,7$ \\
\hline \multicolumn{4}{|l|}{ DIAGNOSIS } \\
\hline Neoplasms of gastrointestinal tract & 60 & 39,7 & $31,9-48,0$ \\
\hline Biliary tract disease & 41 & 27,2 & $20,3-35,0$ \\
\hline Liver disease & 34 & 22,5 & $16,3-30,1$ \\
\hline
\end{tabular}

95\% CI=confidence interval of $95 \%$

Table 2 shows the mean values of dominant and non-dominant adductor pollicis hands which are presented according to the classification of nutritional status by arm circumference, triceps skinfold thickness, arm muscle circumference, BMI and corrected arm muscle area parameters, and it was observed that the values of them are significantly lower in malnourished patients only for arm circumference, cutaneous tricipital fold and BMI.

Figure 1 shows the prevalence of malnutrition considering the cutoff values for thickness of dominant and non-dominant hands according to Bragagnolo ${ }^{5}$.
TABLE 2 - Distribution mean and standard deviation of the dominant and non-dominant hands according to the classification of nutritional status in surgical patients

\begin{tabular}{|c|c|c|c|c|c|c|c|}
\hline \multirow{2}{*}{\multicolumn{2}{|c|}{$\begin{array}{c}\text { ESTADO } \\
\text { NUTRICIONAL }\end{array}$}} & \multicolumn{3}{|c|}{ DAPM } & \multicolumn{3}{|c|}{ NDAPM } \\
\hline & & \multirow{2}{*}{$\begin{array}{l}(\mathrm{n}) \\
65\end{array}$} & $\mathrm{M} \pm \mathrm{SD}$ & \multirow{3}{*}{$\begin{array}{c}\mathbf{p}^{*} \\
0,007\end{array}$} & \multirow{3}{*}{$\begin{array}{l}\text { (n) } \\
60 \\
69\end{array}$} & \multirow{3}{*}{$\begin{array}{c}M \pm S D \\
13,48 \pm 3,25 \\
11,77 \pm 3,17\end{array}$} & \multirow{3}{*}{$\begin{array}{c}p^{*} \\
0,003\end{array}$} \\
\hline \multirow{2}{*}{$A C$} & Eutrophic & & $14,15 \pm 3,66$ & & & & \\
\hline & Malnourished & 71 & $12,51 \pm 3,30$ & & & & \\
\hline \multirow{2}{*}{ TSF } & Eutrophic & 66 & $14,72 \pm 3,20$ & \multirow{2}{*}{0,000} & 64 & $13,76 \pm 2,98$ & \multirow{2}{*}{0,000} \\
\hline & Malnourished & 80 & $12,14 \pm 3,48$ & & 75 & $11,43 \pm 3,33$ & \\
\hline \multirow{2}{*}{ AMC } & Eutrophic & 72 & $13,03 \pm 3,30$ & \multirow{2}{*}{0,979} & 67 & $12,42 \pm 2,83$ & \multirow{2}{*}{0,806} \\
\hline & Malnourished & 74 & $13,32 \pm 3,84$ & & 73 & $12,56 \pm 3,79$ & \\
\hline \multirow{2}{*}{ CAMa } & Eutrophic & 91 & $13,84 \pm 3,45$ & \multirow{2}{*}{0,470} & 89 & $12,91 \pm 3,43$ & \multirow{2}{*}{0,770} \\
\hline & Malnourished & 46 & $12,62 \pm 3,28$ & & 42 & $11,84 \pm 2,60$ & \\
\hline \multirow{2}{*}{ BMI } & Eutrophic & 117 & $13,97 \pm 3,42$ & \multirow{2}{*}{0,000} & 111 & $13,11 \pm 3,7$ & \multirow{2}{*}{0,000} \\
\hline & Malnourished & 31 & $10,83 \pm 2,96$ & & 30 & $10,30 \pm 3,10$ & \\
\hline
\end{tabular}

* Student t-test for two independent variables; $\mathrm{BMI}=$ body mass index; $\mathrm{AC}=$ arm circumference; TSF=triceps skinfold; $A M C=a r m$ muscle circumference; $\mathrm{CAMa}=$ corrected arm muscle area; $\mathrm{DAMP}=$ hand dominant adductor pollicis; NDAMP hand non-dominant adductor pollicis

Table 3 shows the distribution of nutritional status according to the dominant and nondominant hands adductor pollicis in relation to gender, life stage, diagnosis, and weight loss. It can be seen that eutrophia is most common in men and women malnutrition. In adults it was showed a significant frequency of normal weight compared to the elderly and the clinical diagnosis and weight loss were not associated with nutritional status by measuring the APM.

TABLE 3 - Frequency of nutritional status by dominant and non-dominant hands in relation to gender, life stage, diagnosis and percentage of weight loss in surgical patients

\begin{tabular}{|c|c|c|c|c|c|c|c|c|}
\hline & \multicolumn{3}{|c|}{ DAPM } & \multicolumn{5}{|c|}{ NDAPM } \\
\hline & Malnutrition & Eutrophia & Total & $\mathrm{p}^{*}$ & Malnutrition & Eutrophia & Total & $\mathrm{p}^{*}$ \\
\hline & $\mathrm{N} \quad(\%)$ & $\mathrm{N} \quad(\%)$ & $\mathrm{N} \quad(\%)$ & & & & $\mathrm{N} \quad(\%)$ & \\
\hline $\begin{array}{l}\text { GENDER } \\
\text { Male } \\
\text { Female }\end{array}$ & $\begin{array}{ll}25 & (30,5) \\
57 & (69,5)\end{array}$ & $\begin{array}{ll}36 & (54,5) \\
30 & (45,5)\end{array}$ & $\begin{array}{ll}61 & (41,2) \\
87 & (58,8)\end{array}$ & 0,003 & $\begin{array}{l}28(31,8) \\
60(68,2)\end{array}$ & $\begin{array}{l}30(56,6) \\
23(43,4)\end{array}$ & $\begin{array}{ll}58 & (41,1) \\
83 & (58,9)\end{array}$ & 0,004 \\
\hline $\begin{array}{l}\text { STAGE OF LIFE } \\
\text { Adults } \\
\text { Seniors }\end{array}$ & $\begin{array}{ll}46 & (56,1) \\
36 & (43,9)\end{array}$ & $\begin{array}{l}47(71,2) \\
19(28,8)\end{array}$ & $\begin{array}{ll}93 & (62,8) \\
55 & (37,2)\end{array}$ & 0,059 & $\begin{array}{l}53(60,2) \\
35(39,8)\end{array}$ & $\begin{array}{l}38(71,7) \\
15(28,3)\end{array}$ & $\begin{array}{ll}91 & (64,5) \\
50 & (35,5)\end{array}$ & 0,168 \\
\hline $\begin{array}{l}\text { DIAGNOSIS } \\
\text { Neoplasms gastrointestinal tract } \\
\text { Biliary tract disease } \\
\text { Liver disease } \\
\text { Others }\end{array}$ & $\begin{array}{l}21(25,6) \\
18(22) \\
32(39) \\
11(13,4)\end{array}$ & $\begin{aligned} 20 & (30,3) \\
15 & (22,7) \\
26 & (39,4) \\
5 & (7,6)\end{aligned}$ & $\begin{array}{ll}41 & (27,7) \\
33 & (22,3) \\
58 & (39,2) \\
16 & (10,8)\end{array}$ & 0,693 & $\begin{array}{c}24(27,3) \\
19(21,6) \\
36(40,9) \\
9(10,2)\end{array}$ & $\begin{array}{c}15(28,3) \\
12(22,6) \\
21(39,6) \\
5(9,4)\end{array}$ & $\begin{array}{lr}39 & (27,7) \\
31 & (22) \\
57 & (40,4) \\
14 & (9,9)\end{array}$ & 0,996 \\
\hline $\begin{array}{l}\text { \% WEIGHT LOSS } \\
\text { Severe } \\
\text { Not Severe }\end{array}$ & $\begin{array}{ll}43 & (52,4) \\
39 & (47,6)\end{array}$ & $\begin{array}{ll}26 & (39,4) \\
40 & (60,6)\end{array}$ & $\begin{array}{ll}69 & (46,6) \\
79 & (53,4)\end{array}$ & 0,114 & $\begin{array}{l}47(53,4) \\
41(46,6)\end{array}$ & $\begin{array}{l}21(39,6) \\
32(60,4)\end{array}$ & $\begin{array}{ll}68 & (48,2) \\
73 & (51,8)\end{array}$ & 0,113 \\
\hline
\end{tabular}

${ }^{*}$ Chi-square test. DAMP $=$ hand dominant adductor pollicis; NDAMP hand non-dominant adductor pollicis 


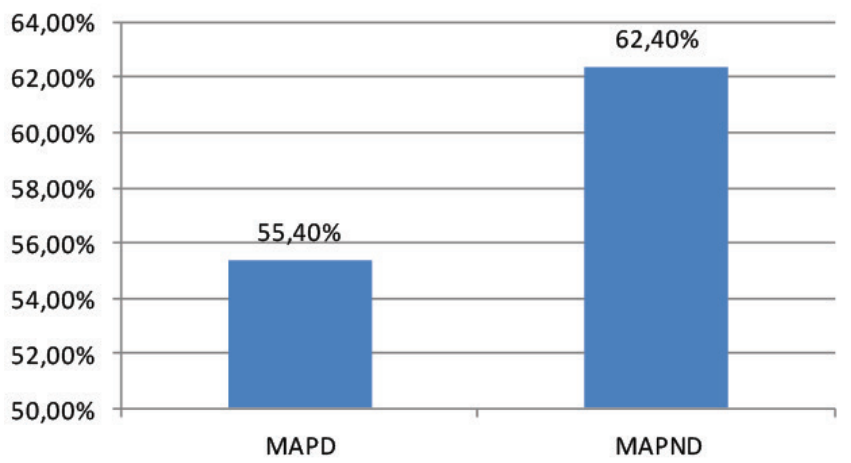

$\mathrm{DAMP}=$ hand dominant adductor pollicis; NDAMP hand non-dominant adductor pollicis

FIGURE 1 - Frequency of malnutrition in surgical patients according to the dominant and non-dominant hands

\section{DISCUSSION}

Nutritional assessment performed immediately on admission of the patient, allows the establishment of an early diet therapy plan with the objective of improving the nutritional status and minimize the risk of postoperative complications. The results of this study point women as the majority in the study, a fact that may be explained by the increased demand of this group to health services. The elderly, once there are limitations to surgical procedures due to age, showed up as minority, although the diagnostic cited is similarly frequent to adults and elderly. The profile of patients was very similar to patients studied by Bragagnolo et al. ${ }^{5}$ where the average age was around 50 years and mostly women, in addition to diagnostic prevalence of neoplasms of gastrointestinal tract.

Few studies have used the measurement of APM as a nutrition assessment parameter, and consequently cutoff points were suggested for some specific clinical conditions $2,5,13,22$. The measure shows that dominant is often higher than the nondominant hands adductor pollicis, justified by the fact that this muscle is more worked in the dominant hand than in the non-dominant. There is even a preference to measure the dominant hand since the most exercised muscle tends to shrink more rapidly in a situation of malnutrition ${ }^{2}$ as a result of apathy.

In the current study, it was observed that the mean values of dominant and non-dominant hand adductor pollicis were lower in those patients that were malnourished according to arm circumference, triceps skinfold thickness and BMI indicators. Gonzalez ${ }^{16}$ that evaluated healthy subjects observed a significant association between measured APM only with BMI. De Oliveira ${ }^{22}$ in a study involving 143 kidney patients, observed that there was significant association of APM with BMI, arm circumference, arm muscle circumference and corrected arm muscle area.

However, Rezende et al. ${ }^{23}$ assessed 168 patients with surgical indication using Subjective Muscle Assessment which includes the APM in its parameters noted that there was good agreement between the Subjective Muscle Assessment and the objective methods of nutritional assessment in preoperative patients.

Both the arm muscle circumference as corrected arm muscle area, commonly cited as good parameters for muscle reserves, did not show a good correlation with APM. It is known that classical anthropometric assessment reflects the degree of malnutrition ${ }^{3}$, though these bodily changes arise only after a period of malnutrition installed. Functional changes show-up early while the anatomical, started later, which can explain that conventional parameters are not able to assess the condition of malnutrition during acute phase ${ }^{6}$.

It is believed that loss of labor leads to reduced thickness of APM independent of the underlying disease and its consequent catabolism ${ }^{20}$, justifying the muscle loss observed by the APM without, however, obtaining significant muscle loss by arm muscle circumference and corrected arm muscle area, a result that corroborates with the findings of Freitas et al. ${ }^{13}$, who evaluated 82 oncologic patients who underwent nutritional assessment by anthropometry and classical measurement of APM. The values of by arm muscle circumference and corrected arm muscle area were indicative of preserving muscle mass while triceps skinfold thickness, pointed severe depletion of fat mass, which was also observed in the current study, where it was significantly lower in patients classified as malnourished by APM in both hands.

In the present study, there was a prevalence of malnourished patients using the adductor pollicis muscle measure as an indicator of nutritional status. Due to the scarcity of similar studies in the literature, it was not possible to compare the incidence of malnutrition through the thickness of APM found with other studies, although malnutrition is a frequent finding from other parameters of nutritional assessment in surgical patients, as in the study of Dias and Burgos ${ }^{11}$.

Higher frequency of malnutrition in females and eutrophic males was observed when compared to sex in relation to nutritional status by measuring the APM, which can be explained by differences in body composition between genders, in addition to the fact that men perform activities that require greater effort and as a consequence, development of the muscles in question. It is noteworthy that the cutoffs used in the given study did not differ for men and women, males may have overestimated muscle reserves. 
Freitas et al. ${ }^{13}$ found in their study different means to measure the APM for gender, being higher in men. Rezende et al. ${ }^{23}$ used gender as a parameter for assessing the extent of APM cutoff points according to the proposed by Lameu et al. ${ }^{18}$, finding a higher rate of malnutrition among the male population.

Regarding the stage of life, Rezende et al. ${ }^{23}$ also noted that the measurement of APM is superior in adults less than 58 years, preservation of muscle around 65 years and decrease in the eighth decade of life, which may point to the need for specific cutoff points for different stages of life, as proposed by Lameu et al. ${ }^{18}$. In the present study, adults were classified mostly as eutrophic while the elderly malnutrition was more common, a fact that may be explained by the uniformity of the cutoff point used, underestimating the actual muscle in the elderly group. In a study proposed by Dias and Burgos $^{11}$, malnutrition was more prevalent in the elderly, since these were mostly in their series.

In the current study, the prevalence of malignancy as the principal diagnosis in patients was observed. In stratified sampling, when the APM associated with nutritional status, was observed more frequently malnutrition in liver diseases. The literature brings no studies detailing the underlying disease in relation to APM more broadly, making it impossible to compare the data from this study.

The percentage of weight loss is a benchmark to detect weight changes and their evolution over time ${ }^{8}$. Involuntary loss in a short period is indicative of nutritional deficits and was considered as an indicator of poor surgical prognosis ${ }^{12}$. Oliveira 22 observed good correlation of APM with percentage of weight loss, corroborating the findings of this study.

\section{CONCLUSION}

The APM has proved to be a good method to diagnose muscle depletion and malnutrition in surgical patients.

\section{REFERENCES}

1. Andrade F.N., Lameu E.B., Luiz R.R.: Musculatura adutora do polegar: um novo índice prognóstico em cirurgia cardíaca valvar. Revista da SOCERJ Set/Out 2005 vol 5 384-91.

2. Andrade $P$ VB, Lameu EB: Espessura do músculo adutor do polegar: um novo índice prognóstico em pacientes clínicos. Rev Bras Nutr Clin, 2007; 22(1): 28-35.

3. Blackburn G.L, Bistrian B.R., Maini B.S., Schlamm H.T., Smith M.F. Nutritional And Metabolic Assessment Of The Hospitalized Patient. Jpen 1977; 1:11-22.
4. Blackburn GL, Thornton PA. Nutritional assessment of the hospitalized patients. Med Clin North Am. 1979; 63(5):1103-15

5. Bragagnolo R., Caporossi,FS, DOck-Nascimento, DB, AguilarNascimento, JE. Espessura Do Musculo Adutor Do Polegar: Um Método Rápido E Confiável Na Avaliação Nutricional De Pacientes Cirúrgicos.Rev Col Bras Cir [ periódico na internet] 2009; 36(4): Disponível em URL: http://www.scielo.br/rcbc.

6. Bray GA, Greenway FL, Molitch ME. Use of anthropometric measures to assess weight loss. Am J Clin Nutr 1978;31:769-73.

7. Celano RMG, Ebran Neto, J, Bottoni A, Gagliard D. Megaesôfago não-avançado. Avaliação nutricional no pré-operatorio. Ver Col Bras Cir [periódico na Internet]. 2007; 34(3). Disponível em URL: http://www.scielo.br/rcbc.

8. Cerezo L. Diagnóstico del estado nutricional y su impacto em el tratamento del câncer. Oncologia 2005; 28 (3): 129-34.

9. Chumlea WC, Roche AF, Steinbaugh, ML. Estimating stature from knee height for persons 60 to 90 years of age. J Am Geriatr Soc 1985; 33 (2): 116-20.

10. Correia MITD. Desnutrição. In: Teixeira Neto F. Nutrição Clínica. Rio de Janeiro: Guanabara Koogan, 2003.p. 159-163.

11. Dias C. A., Burgos M. G. P. A. Diagnóstico Nutricional De Pacientes Cirúrgicos. Arquivo Brasileiro De Cirurgia Digestiva, 2009; 22(1): 2-6.

12. Diestel CF, Horst NL, Sampaio ARD, Mannarino IC, Daly JM. Nutritional Support of the Cancer Patient. CA Cancer J Clin 1998; 48: 69-80.

13. Freitas BJSA, Mesquita LC, Teive NJV, Souza SR: Antropometria clássica e músculo adutor do polegar na determinação do prognóstico nutricional em pacientes oncológicos. Revista Brasileira de Cancerologia, 2010; 56 (4): 415-422.

14. Frisancho A. Triceps skinfold and upper arm muscle size norms for assessment of nutritional status. Am. J. Clin. Nutr. (1974) 27, 10521058

15. Frisancho AR. Anthropometric standards for the assessment of growth and nutritional status. Michigan: The University Academic Press; 1999. P.189.

16. Gonzalez MC et al.: Adductor pollicis muscle: Reference values of its thickness in a healthy population. Clinical nutrition (2009), doi:10.1016/j.clnu.2009.08.012.

17. Instituto Nacional de Câncer (Brasil). Estimativas 2010: Incidência de Câncer no Brasil. Rio de Janeiro: INCA, 2009.

18. Lameu E. B., et al. Adductor pollicis muscle reflects the muscle compartment and may be used as a new anthropometric parameter for nutritional assessment. Curr Opin Clin Nutr Metab Care, 2004; 7(3): 293-301.

19. Lipschitz DA. Screening for nutritional status in the elderly. Nutr. in old age. 1994; 21:55-67.

20. Metter EJ, Talbot LA, Schranger M. Skeletal muscle strength as a predictor of all-cause mortality in healthy men. J Gerontol A Biol Sci Med Sci 2002; 57:B359-365.

21. Moreira TR, Moraes CMB. Abordagem nutricional no tratamento e prevenção do melanoma. Rev bras nutr Clin 2007; 22(4):311-16.

22. Oliveira $\mathrm{CMC}$, et al.Adductor pollicis muscle thickness: A promising anthropometric parameter for patients with chronic renal failure. National Kidney Foundation, 2011.

23. Rezende IFB, et al. Avaliação muscular subjetiva como parâmetro complementar de diagnóstico nutricional em pacientes no préoperatório. Rev Nutr, Campinas, 20 (6): 603-613, nov/dez., 2007.

24. Silva M K S, Félix DS. Uso da antropometria na avaliação do estado nutricional. Rev Bras Nutr Clin, 1998; 13(1): 74-80.

25. Waitzberg D.L., Caiaffa W.T., Correia M.I.T.D. Hospital malnutrition: the Brazilian national survey (IBRANUTRI): a study of 4000 patients. Nutrition, 2001; 17: 575-80.

26. Weimann A., Braga M, Harsanyi L., et al. ESPEN Guidelines on Enteral Nutrition: Surgery Including Organ Transplantation. Clin Nutr, 2006; 25: 224-44.

27. World Health Organization (WHO). Obesity: preventing and managing the global epidemic. Report of a WHO Consultation of Obesity. Geneva, 1997. 